\title{
Eläinhenget - Keskustelu eläinten kuolemattomista sieluista spiritualistisessa Light-lehdessä Britanniassa 1887
}

\author{
MARJO KAARTINEN \\ Professori, Kulttuuribistoria \\ Turun yliopisto \\ mkaartin@utu.fi
}

\begin{abstract}
ABSTRAKTI
Artikkeli tarkastelee brittiläisen, spiritualistisen Light-lehden keskustelua eläinten hengistä ja sieluista vuonna 1887. Artikkeli osoittaa, miten spiritualistien kokemusperäinen tieto siitä, että tuonpuoleisessa oli ihmishenkien lisäksi myös eläinten henkiä, vahvisti keskustelua eläinten roolista ihmisten maailmassa. Keskusteluun liittyi nopeasti myös eläinsuojelullinen ja antivivisektionistinen vire.
\end{abstract}

KEYWORDS: spiritualismi; eläinsuojelu; vivisektio

\section{Johdanto}

Vuonna 1887 käytiin keskustelua toislajisten ${ }^{1}$ eläinten sieluista, hengistä ja etenkin sielujen kuolemattomuudesta lontoolaisessa, spiritualistisessa Light-lehdessä. Keskustelu käytiin lehden lukijakirjeiden (Correspondence) osastossa. Tarkastelen tässä artikkelissa kysymyksiä, jotka lehden lukijat mielsivät relevanteiksi pohtiessaan mahdollisuutta siihen, että eläimillä olisi kuolematon sielu. Tutkin esimerkkitapauksen avulla 1800-luvun jälkipuolen esoteerisen ${ }^{2}$ kentän suhdetta eläimiin ja pohdin myös, miten esoteerikot mielsivät eläimet suhteessa ihmisiin. Käytän kulttuurihistoriallisen luennan menetelmiä. Kuten tässäkin artikkelissa, kulttuurihistoria tarkastelee tyypillisesti arkisia merkityksenantoja pikemminkin kuin oppijärjestelmiä ja analysoi niitä alkuperäislähteiden laadullisen luennan avulla. Keskeisten lähteiden lähiluvussa etsitään johtolankoja ja avaimia, 
joiden avulla menneisyyden ihmisten ymmärrys voi avautua.

Spiritualismi oli lähtenyt maailmanvalloitukselleen Yhdysvalloista 1840-luvun lopussa ja vakiinnuttanut neljässä vuosikymmenessä asemansa johtavana niin sanotun modernin esoterian tulkintana ja vakaumuksena. 1800-luvun jälkipuolen esoteerisia virtauksia voi pitää vastapainona tiedettä ja teknistä edistystä korostaneelle ajan hengelle. Spiritualismi oli luonteeltaan epäyhtenäinen liike, mutta olennaista spiritualistien ajattelussa oli tietoisuus henkimaailmasta, siitä, että yhteys kuolleisiin olisi mahdollista saavuttaa konkreettisin keinoin. Spiritualistit tavoittelivat henkimaailmaa välittäjien eli meedioiden avulla, usein spiritualistisissa istunnoissa (séance). Oppiin kuului käsitys kaikkien ihmisten veljeydestä ja sisaruudesta keskenään ja myös ajatus siitä, että teot tässä elämässä vaikuttivat elämään tuonpuoleisessa. Ihmisen sielu oli kuolematon. (Kaartinen \& Leskelä-Kärki 2020; Holm 2019; Kokkinen 2019; Faivre 2010, 78-83; Owen 2004; Treitel 2004; Owen 1989; Braude 1989; Brandon 1983.) Osin spiritualismin piiristä nousi 1870-luvulla spiritualismille kilpailija ja haastaja, teosofia. Nopeasti suurta suosiota saavuttaneen teosofian keulakuvana pidettiin Helena Blavatskya (18311891). ${ }^{3}$ Teosofian ja spiritualismin - ja ylipäänsä esoterian laajan kentän - rajat olivat huokoiset; spiritualistisen Light-lehden keskusteluun osallistuikin myös teosofeja. Siinä missä spiritualistit olivat kiinnostuneita henkien manifestoitumisesta, teosofia painotti itämaista filosofiaa ja sielun matkaa yhä korkeammalle tasolle. Molempien lähtökohtana oli kaiken ykseys, kun pohdittiin ihmisen ja muiden elollisten suhdetta.

Jos ihmisen sielu oli kuolematon, miten oli eläinten, lemmikkikoirien, kissojen ja papukaijojen sielujen laita? Keskustelu eläinten hengistä käynnistyi helmikuussa 1887, jolloin Light-lehteä oli julkaistu jo usean vuoden ajan. Lehti oli vakiinnuttanut asemansa nopeasti kasvaneella spiritualistisen journalismin kentällä. Ensimmäinen numero oli

1 Artikkeli tarkastelee 1800-luvun jälkipuoliskoa, jolloin ihmisen pitäminen eläimenä oli yhä haasteellista, vaikka jo antiikista peräisin oleva pythagoralaisuus esitti lajien ykseyttä ja modernissa tieteessä jo sata vuotta takaperin Carl von Linné oli esittänyt, ettei ihmisen ja orangin välillä voinut havaita mitään eroa - darwinismista puhumattakaan. Toislajisista eläimistä puhuminen olisi anakronistista, joten artikkelissa artikkelin "eläin" ei jatkossa sisällä ihmistä (ks. esim. Roussillon-Constanty \& Thornton 2018).

2 Esoterialla viitataan tässä länsimaisen esoterian tutkimuskentällä käytettyyn käsitteeseen. Aikalaiset puhuivat itsestään tavanomaisemmin okkultisteina. Esoteria määrittyy artikkelissa löyhästi kätketyn tiedon ja ikuisen viisauden etsinnäksi (käsitteistä tarkemmin Kokkinen \& Mahlamäki 2020, 13-16) ja esoteerikko puolestaan tuon kentän toimijaksi. Näin esoteerikko ja okkultisti ovat tässä artikkelissa synonyymisiä siten, että ensimmäinen on tutkimuksen termi, jälkimmäinen aikalaiskäsite. Esoterian valtavan tutkimuskirjallisuuden kentän äärelle pääsee kattavasti teoksen Hanegraaff \& Forshaw \& Pasi (2019) 45-sivuisesta bibliografiasta.

3 Teosofiasta tarkemmin Harmainen (2020, 93-102). 
ilmestynyt tammikuussa 1881 tavoitteenaan olla korkeatasoinen spiritualistinen viikkolehti, ja sitä pidettiinkin koulutetuille spiritualisteille suunnattuna julkaisuna (Light 15.1.1881). Ehkä lehden oppineesta maineesta johtuen sen levikki pysyi alle kymmenessätuhannessa. Julkaistujen lukijakirjeiden perusteella voi päätellä, että lukijakuntaan kuului aivan tavallisia spiritualisteja, joskin on selvää, että kyseessä oli oppineelle keskiluokalle suunnattu julkaisu. Lehti oli alkujaan muotoutunut Lontoon spiritualistisen liiton (London Spiritualist Alliance) äänenkannattajaksi. Vuonna 1884 Light siirtyi seuran yhteydessä toimivalle, mediumismiin keskittyneelle Psyykkisen tutkimuksen kollegiolle (College of Psychic Studies), joka julkaisee lehteä yhä (College History, www-sivu). Tässä artikkelissa tarkastellun keskustelun aikana lehden päätoimittajana oli laajasti tunnettu spiritualisti ja meedio William Stainton Moses (1839-1892). Myöhemmin sen merkittävimpiin taloudellisiin tukijoihin kuului niinikään maineikas spiritualisti Sir Arthur Conan Doyle (1859-1930). Lehden merkityksestä esoterian kentällä kertoo myös se, että sitä seurattiin laajasti maailmalla, myöhemmin Suomessakin niin spiritualistisessa Spiritisti-lehdessä kuin teosofisessa Tietäjässä (esim. Spiritisti 7/ 1909, 12/1909; Tietäjä 1/1910).

Koska spiritualistit havaitsivat aistein toistuvasti kuolleiden eläinten henkiä, olennaiseksi Light-lehden vuoden 1887 lukijakirjekeskustelussa nousi spiritualistien kokemusperäisen tiedon suhde valtavirtaisen kristillisen opin kielteiseen ajatukseen eläinten kuolemattomista sieluista. Tämä artikkeli tarkastelee Light-lehdessä käytyä keskustelua ensin sen ensimmäisten julkaistujen kirjeiden näkökulmasta ja pohtii, millaisia tarinoita ja kokemuksia eläinten henkien kohtaamisista lehden lukijoilla oli. Kissa-, koira- ja lintuvainajat valloittivat lukijapalstan. Tämän jälkeen tarkastelu siirtyy keskustelun saamaan uuteen juonteeseen, jossa käytiin pohtimaan laajemmin tapoja ymmärtää kysymys eläimen sielun kuolemattomuudesta. Tällöin nousivat esiin myös teosofien näkemykset kysymyksestä. Kolmas aspekti keskustelussa siirtyi ohitse alkuperäisen kysymyksen eläinten julmaan kohteluun. Etenkin kysymys vivisektiosta oli mitä päivänpolttavin. Lopuksi, ja edelliseen liittyen, artikkeli tarkastelee lyhyesti Light-lehden kirjevirrassa 1800-luvun jälkipuolella käytyä, yhä ajankohtaisempaa keskustelua eläinten kyvyistä. 


\section{Keskustelu käynnistetään}

Keskustelun eläinten sieluista käynnisti Light-lehden helmikuun 19. päivän numerossa nimimerkki J. C.:n kirje. Kirje on otsikoitu kysymysmuotoon "Onko eläimillä sielua?"4 Keskustelu jatkui läpi kevätkauden saman tai hivenen muunnetun otsikon Animals and their Souls alla (Light 12.3.1887, 117). Yhteensä keskustelussa julkaistiin 17 kirjettä5 ja kaksi muuta teemaan liittyvää kirjettä.

Kysymys siitä, oliko eläimillä sielu, oli lukuisille esoteerikoille olennainen. Merkittävä osa spiritualisteista ja myös teosofeista katsoi olevansa myös kristittyjä, joten kysymys oli myös haasteellinen. Tällöin heidänkin tuli mukailla valtakirkkojen vuosisatoja vanhaa jyrkkää vastausta kysymykseen eläinten ihmisen kaltaisesta sielusta. Vastaus oli ollut "ei", sillä tärkein ihmisen eläimistä erottava tekijä oli nimenomaan ihmisen kuolematon sielu (French 1975, 351-72, 377; Bates 2017, 43-45). ${ }^{6}$ Tätä oppia vastaan tuntui nousevan spiritualistien kokemusperäinen tieto. Mitä enemmän spiritualistit osallistuivat mediumistisiin seansseihin tai kanavoivat automaattikirjoittamisen tai -piirtämisen kautta tietoa tuonpuoleisesta, sitä enemmän he tuntuivat saavan vihjeitä siitä, että ihmissielut eivät olleet rajan takana yksin. Vaikka merkittävä osa spiritualisteista piti itseään kristittyinä, kokemuksen tuoma tieto eläinten sieluista ohitti kirkon oppijärjestelmän. Tämän kokemuskentän rikkaudesta kertoo Light-lehden keskustelu.

Nimimerkki J. C. haki vastakaikua omille kokemuksilleen kirjoittaessaan lehteen. Mukaan liitetystä ystävän kirjeestä ilmenee, että nimimerkki on rouva C., joka oman kertomansa mukaan on useamman lapsen äiti ja leski. Hän on ryhtynyt kirjoittamaan kirjettään, koska hänellä on tuoreita, erikoisia kokemuksia. Hän haluaa erityisesti kysyä, onko muilla lehden lukijoilla ollut samankaltaisia kokemuksia. Rouva C. kirjoittaa, kuinka hän "tänä iltana" keskustellessaan ystävänsä kanssa säikähti heidän edestään kulkeneen pienen valkoisen koiran hahmoa. Hän kirjoittaa, kuinka koira katosi keskellä huonetta. Verbi on kursivoitu myös julkaistussa alkuperäistekstissä, mikä on omiaan painottamaan tilanteen dramaattisuutta ja toden tuntua. Huoneen ovi oli kiinni ja ystävät tutkivat huoneen, mutta minkäänlaista eläintä he eivät etsinnöistään huolimatta löytäneet. (Light 19.2.1887, 86.)

4 "Have animals souls?"

5 Näistä julkaistiin keskustelunavaus ja sitä tukeva kirje helmikuussa, maaliskuussa julkaistiin viisi vastausta, huhtikuussa neljä (ja yksi teemaan liittyvä) ja toukokuussa vielä kuusi kirjettä ja yksi muu teemaan liittyvä teksti.

6 French (1975, 345-47) ja Bates (2017, erit. 48-50) korostavat kristittyjen parissa näkemysten eläinten kuolemattomuudesta rajoittuneen protestanttisten nonkonformististen ajattelijoiden näkemyksiin. 
Toinen rouva C:n kuvaama tapaus liittyi eri koirayksilöön. Hän kirjoittaa: "Eräänä yönä heräsin ja näin koiran hahmon istuvan sänkyni vieressä matolla. Katsoin sitä ja se katsoi minua, asettui makuulle ja katseli minua kiintymyksellä. Menin koskettamaan sitä ja se katosi!" J. C. kertoo, että hahmo näytti hänellä aikanaan 12 vuotta olleelta Figaro-koiralta. Kolmas hänen kertomansa tapaus liittyy hänen kahdeksanvuotiaaseen tyttäreensä. Tyttönen oli vastikään kiintynyt kovasti naapurin suureen noutajaan, mutta koira kuoli. Kolme päivää kuoleman jälkeen tyttö kertoi äidilleen nähneensä koiran mennessään nukkumaan. Hän oli ollut aivan valveilla. Hän oli kertonut, kuinka koira seisoi ikkunan vieressä, katseli häntä - ja katosi sitten verhoon. Viimeinen J. C.:n kertoma, jo kauemman aikaa sitten sattunut tapaus liittyy tällä kertaa lintuun, miesvainajan Australiasta tuomaan kakaduun. J. C. selostaa: "Lintu oli meillä monta vuotta, kunnes mieheni siirtyi korkeampaan elämään. Lintu kaipasi häntä. Yhtenä yönä heräsin ja näin sen lentävän huoneeni poikki ja katoavan ikkunaan. Olin varma, että se oli päässyt irti, mutten voinut nähdä sitä. Aamulla lintu löydettiin kuolleena häkissään, häkin luukku suljettuna. Minä aina suljen oveni yöksi”. (Light 19.2.1887, 86.) Tähän päättyy J. C.:n kirjoitus. Hän halusi kirjeellään epäilemättä vahvistusta sille, etteivät nämä hänen ja tyttären kokemukset olleet spiritualistien joukossa ainutkertaisia tai tavattomia. Ehkä hän kaipasi myös tulkintoja näistä tapahtumista. Hän oli epäilemättä keskustellut omassa piirissään kokemuksistaan ja piti niitä merkittävinä, koska halusi välittää ne kanssaspiritualisteille.

Light julkaisi J. C.n kirjeen alla hänen ystävänsä W. B. Lumleyn (osoitteesta Fairfield house, Folkestone) vahvistavan todistuslausunnon. Lumley vakuuttaa nähneensä koiran J. C.:n olohuoneessa ja etsineensä sitä. Hän myös vakuuttaa, että etsinnöistä huolimatta eläintä ei löydetty. Kirjeen lopusta päätellen Lumley oli ystävättärensä tavoin spiritualisti: "On suuri ilo lisätä todistukseni spiritualististen ilmiöiden puolesta puhuvan laajan todistusaineiston joukkoon". (Light 19.2.1887, 86.) On mahdoton sanoa, olivatko kirjoittajat tietoisia esitetyn kysymyksen kiistanalaisuudesta ei vain kirkon vaan myös spiritualistien keskuudessa, mutta he suhtautuivat näkemiinsä eläinkummituksiin suoraviivaisesti suuremmin havaintojansa epäilemättä.

Kysymys eläinten mahdollisista sieluista oli noussut esiin jo spiritualismin ensimmäisen sukupolven aikana. Yksi merkittävimmistä varhaisista brittiläisistä spiritualisteista, Daniel Dunglas Home (1833-1886) oli ottanut kantaa tematiikkaan 1860-luvun lopulla. Hän oli erittäin vaikutusvaltainen ja esimerkiksi tsaarin hovissa hän oli tärkeässä roolissa myös spiritualismin leviämisessä Venäjällä. Hän ei kuitenkaan sallinut eläimille korkeaa sielun tasoa ja pysytteli kristinuskon raamittamassa maailmankuvassa. Tämä ilmenee seuraavasta Homen lesken julkaisemasta kertomuksesta. Huhtikuussa 1869 
Home näki transsissa pienen valkoisen koiran ja ymmärsi, että koira on juuri kuollut. Tapahtumien todistaja, lordi Adare kertoi, että Home tiesi koiran olleen sairas, muttei koiran kuolema voinut olla meedion tiedossa. Home kertoi transsissa, että koiran kuoltua se ei ole kuitenkaan tuhoutunut. "Se on kuin pieni sähkökipinä, pieni valopallo." Home esitti, että tämä valopallo tulee tulevaisuudessa sulautumaan muuhun, "johonkin korkeampaan eläinelämän muotoon". Hänen tietonsa mukaan valopallolla ei ole tietoisuutta, sillä koira ei ole tarpeeksi korkealla olemassaolon tasolla voidakseen säilyttää yksilöllisyytensä. Kun Homelta kysyttiin, oliko tuonpuoleisessa eläimiä ja olisiko niistä mikään elänyt aiemmin maan päällä, hän vastasi, että kauneus edellyttää vaihtelua ja että myös henkimaailmassa sitä on. Hän ei kuitenkaan esittänyt, että tuonpuoleisessa olevat eläimet olisivat aiemmin olleet maan päällä. Pikemminkin hän totesi, että "minusta näyttää siltä, että ne eivät olisi. Tiedän vain, että ne ovat siellä ja näen, että maan eläinten elämä sulautuu lopulta muihin muotoihin. Minulla ei ole tietoa, että eläimemme olisivat koskaan jatkaneet elämäänsä henkimaailmassa”. (Dunglas Home 1890, 271.) ${ }^{7}$ Homen käsitys jatkaa näin kristillistä näkemystä eläimistä ihmisten hyödykkeinä: tuonpuoleisessa niillä oli vain esteettinen tehtävä. Käsitys eläinten pelkästä valopalloisuudesta ja sielujen väliaikaisuudesta ei kuitenkaan päätynyt jaetuksi spiritualistien keskuudessa, mistä kertoo selkeästi Light-lehdessä puhjennut keskustelu. Heidän kokemustensa kertoi toista.

\section{Kiireisimmät vastaukset}

Ensimmäiset vastaukset J. C.:n pyyntöön kuulla muiden kokemuksista julkaistiin jo kahden viikon kuluttua ilmestyneessä Lightin numerossa. ${ }^{8}$ Kaksi vastausta julkaistiin maaliskuun 5. päivän numerossa. Croydonista tulleessa kirjeessä kerrottiin lontoolaisella kadulla muutama vuosi aiemmin sattuneesta tapauksesta. Nimimerkki J. R. kertoo saaneensa riesakseen suuren koiran: "Se koetti niin sanoakseni kihnuttaa jalkaani vasten." Hän kertoo kysyneensä kadulla kohtaamaltaan liiketuttavaltaan, oliko koira tämän, mutta sai kieltävän vastauksen. Liiketuttava pyysi J. R.:ää kuvailemaan koiran. Kuvaus vastasikin liiketuttavan aiempaa koiraa, jonka hän oli kuristanut sen suututettua omistajansa - mitä tekoa, liiketuttava oli hiljaa lisännyt, hän "oli sittemmin hivenen katunut". (Light 5.3.1887, 108.) Tällainen teko on nykypäivän näkökulmasta hätkähdyttävä, mutta se ehkä oli sitä myös J. R.:n mielestä, sillä hän päättää lyhyen kirjeensä

7 Spiritualistipiireissä oli myös kerrottu venäläisen kreivi Lvovin koirahengen tapauksesta, jossa pariisilaisessa salongissa vuonna 1877 Lvovin lapsuudenystävä, suuri valkoinen newfoundlandinkoira näyttäytyi meediolle kreivin vieressä. The Spiritual Review, August 1900, 147-48.

8 On tietysti mahdotonta tietää, julkaisiko lehti teemaan kaikki lähetetyt kirjeet vai ei. 
tähän lauseeseen - mahdollisesti vihjatakseen, että ei ollut ihmekään, että koira ilmestyi kummittelemaan kuristajalleen.

Jälkimmäinen kirjeistä on päivätty Readingissä 21.2., kaksi päivää J. C.:n kysymyksen ilmestymisestä. Teema on inspiroinut nopeaan vastaukseen. Nimimerkki G. H. W. kirjoittaa kahden viikon takaisesta kokemuksestaan kissan "hahmon" kanssa. Hän mainitsee olevansa mediumistinen ja että hänellä on ruumiistairtoamiskokemuksia. Hän oli herännyt yöllä tunteeseen, että sängyssä oli kissa, jonka hän tunsi "hengellisesti" - ja jota hänen henkensä halusi paeta inhosta. Hän oli kuitenkin tietoinen siitä, että hänen ruumiinsa oli yhä sängyssä. Kokemus oli ollut kaikin puolin epämiellyttävä, ja nimimerkki haluaakin paljastaa, ettei pidä kissoista. Herättyään hän tiedusteli palvelijattareltaan, olisiko joku naapureista mahdollisesti viime aikoina menettänyt kissan. Palvelijatar ei sanonut kuulleensa mitään sellaista, mutta hänen oman sisarensa kissa oli kuollut sunnuntaina. Palvelijatar oli jopa ollut viime yönä sisarensa luona ja kertoi, että hän useinkin hoiti häneen hyvin kiintynyttä kissaa. (Light 5.3.1887, 108.) ${ }^{9}$ Tällekin eläinhengelle löytyi näin alkuperä.

Nimimerkki J. H. G. puolestaan kirjoitti, kuinka eräs meedio oli kertonut hänelle, että häntä seurasi huoneeseen puudeli. Koska elävää koiraa ei ollut näkyvillä, tuli päätellä, että kyseessä olisi puudelin henki. Kirjoittajalla olikin ollut puudeli yksitoista vuotta jatkuvana seuralaisenaan, mutta se oli kuollut kaksi vuotta aiemmin. J. H. G. oli meedion havainnosta niin otettu, että hän oli kirjoittanut bostonilaiselle spiritualistien Banner-piirille ${ }^{10}$ ja tiedustellut selitystä tällaiselle. Sieltä oli vastattu, että koira oli elämänsä aikana tullut niin kiintyneeksi kirjoittajaan, että kuolemankin jälkeen se seurasi omistajaansa. Tällaisessa vastauksessa lähtökohtana on eläimen sielun kuolemattomuuden itsestäänselvyys.

\section{Viittauksia muiden oppijärjestelmien käsityksiin}

Light-lehden kirjeenvaihdossa pohdittin myös sitä, miten eri uskonnoissa on suhtauduttu eläinten sieluihin. E. M. pohti kysymystä reilun palstan verran maaliskuun 12. päivän

9 Mainittakoon, että vihjeitä eläimiä inhoavien kokemuksista eläimistä tuonpuoleisessa löytyi laajemminkin. Nimimerkillä S. oli kerrottavana kokemuksia bostonilaisista seansseista, joissa hän oli kohdannut useinkin viitteitä koirista taivaassa. Hän ilmoittaa inhoavansa koiria, muttei myöskään näe syytä, mikseivät ne asuttaisi "alempia sfäärejämme". (Light 7.5.1887, 208.) Tämä osoittaa ainakin sen, että pelkästään viktoriaanisen kulttuurin "lemmikkikultti" ei tuottanut myönteistä suhtautumista kirkonvastaiseen uskoon eläinten sielujen kuolemattomuudesta.

10 Piiri toimi bostonilaisen The Banner of Light -lehden ympärillä (The Banner of Light, February 91867 ). 
numerossa. Hän painotti, että kysymys "onko eläimillä sielu" on väärin asetettu, koska on itsestään selvää, että kaikilla eläimillä on sielu. Kysymys oli sitä vastoin sielun laadusta, sen luonteesta. Kirjoittaja muistuttaa, että muinaiset oppineet pitivät kiistattomana, että eläimillä oli juuri tällainen kuolematon sielu ja vieläpä että sielu ei vain ollut kuolematon vaan se myös vaelsi useiden ruumiiden kautta. Sielunvaelluksen ytimessä oli tietysti ajatus, että sielu vaelsi eri tasoilta korkeammalle, kunnes saavutti ihmisen ruumiin. (Light 12.3.1887, 117.)

Sielunvaellusoppi ei sellaisenaan kuulunut spiritualismin lähtökohtiin, ja E. M.:n kirjoitus vihjaakin, että hän on saanut vaikutteita teosofiasta. Hän viittaa The Theosophist -lehteen ja sen tuoreeseen, helmikuiseen numeroon (Light 12.3.1887, 117), muttei tästä huolimatta viittaa Blavatskyn peräti kolmiosaiseen, vuosi takaperin juuri tuossa lehdessä ilmestyneeseen pohdintaan samaisella otsikolla "Onko eläimillä sielua?", jossa lopputulema on myönteinen. Tähän artikkeliin palataan hetken kuluttua. Kirjoituksessaan E. M. paheksuu niitä lukemattomia okkultistisia kirjoituksia, joissa eläimet tuomitaan pahoiksi ja alhaisiksi - mitä kautta ihmisen julmuus ja itsekkyys voidaan sitten oikeuttaa (Light 12.3.1887, 117). Hän haluaa vedota spiritualisteihin, jotta he kokisivat eläinten hyvän kohtelun velvollisuudekseen.

On huomattava, että vaikka näissä näkemyksissä elävillä olennoilla on tasa-arvoisesti sielu, kaikki olennot eivät suinkaan ole tasa-arvoisia. Ihminen on vääjäämättä ylempi olento myös teosofian oppirakennelmassa, jossa eläinten ja ihmisten astraaliruumiit kokevat Kama Lokassa erilaisen kohtalon. Kuten Blavatskyn manttelinperijä teosofien keulahahmona Annie Besant (1847-1933) kirjoitti muutama vuosi myöhemmin, eläimiä odottaa toisessa kuolemassa kaikkien astraalipartikkeleiden täydellinen katoaminen, mutta ihminen voi edetä toisesta kuolemasta eteenpäin. (Besant 1893, 32.) ${ }^{11}$ Ihmisen ja eläimen ero käy selkeästi ilmi myös E. M.:n kirjoituksesta, jossa hän huomioi, että retrogressiivinen inkarnaatio eli sielun päätyminen alaspäin suuntautuvasti eläimeen on myös mahdollinen ja pohtii, kuinka ihmiset eläimiä kiduttaessaan alentuvat paitsi ihmisyyden, myös eläinten alapuolelle "aina infernaaliseen saakka - -" (Light 12.3.1887, 117).

Myös keskusteluun maaliskuun puolivälissä osallistunut A. J. Penny ${ }^{12}$ Cullomp-

11 Mainittakoon, että Besant oli ennen teosofista herätystään vahva ja näkyvä vivisektion puolustaja (ks. esim. Li 2012, 11-13). Vivisektion vastustamisen roolista keskustelussa hetken kuluttua.

12 A[nne] J[udith] Penny (os. Brown) (1825?-1893) oli aikanaan ilmeisen tunnettu spiritualisti, joka julkaisi lukuisasti kirjoja ja fokusoitui erityisesti Böhmen tekstien tekemisestä tunnetuksi englanninkieliselle lukijakunnalle. Böhmeä hän piti "mestariopettajana". Vaikka Penny oli aikanaan tunnettu, hänestä ei tunnu löytyvän nykytutkimusta eikä hän esimerkiksi ole saanut elämäkertaa 
tonista toteaa ihmisen olevan eläintä ylempänä, vaikkei kielläkään eläimiltä sielua ja kauhistuu niiden rääkkäämisestä. Hän viittaa mystikko-filosofi Jacob Böhmeen (15751624) todetessaan, kuinka koiran moraaliselle tasolle uponneet ihmiset seuraavassa elämässä ilmenevät koirina viitaten näin pitkäikäiseen kulttuuriseen kuvastoon koirasta potkittuna ja ihmisten pöydästä viskeltyjä luita kaluavana otuksena. Tasa-arvoa Penny ei siis hae, vaan toteaa, että olisi suoranainen häväistys väittää eläinten ja ihmisten olevan samalla tasolla, koska Jumala loi nimenomaan ihmisen omaksi kuvakseen. Hän kirjoittaa uskovansa, että "eläimet ovat potentiaalisesti ihmiskunnan nuorempia veljiä". (Light 19.3.1887, 128.) ${ }^{13}$ Keskustelussa vedottiin myös Raamatun tukeen, kun nimimerkki T. W. kirjoitti lyhyesti huhtikuussa ja kannusti lukemaan Charles L. Ivesin ${ }^{14}$ teosta Bible Doctrine of the Soul, jossa tämä käy lävitse hepreankielisen Raamatun näkemystä sielusta. Tämän mukaan termiä sielu käytetään Raamatussa sekä eläimistä että ihmisistä puhuttaessa. (Light 30.4.1887, 196.) ${ }^{15}$

Lukuisat kirjeiden esiin nostamat kokemukset eläinten kuoleman yli säilyneistä hengistä näyttävät osoittaneen spiritualisteille, että eläimillä oli kirkon johtavan opin vastaisesti kuolematon sielu. Kiinnostavaa tässä on erityisesti se, miten he luottivat omiin ja ystäviensä kokemuksiin arjen tapahtumista ja seansseissa nähdystä. Näillä havainnoilla ja kokemuksilla oli seurauksensa sille, miten spiritualistien tuli ajatella eläimistä myös maan päällä elävinä olentoina.

\section{Eläinten oikeudet ja ihmisen julmuus}

Vaikka eläin oli esoteerikoiden ajattelussa ihmisen alapuolella, liikehdinnän sisällä oli Light-lehden keskustelun pohjalta päätellen vahva eläinsuojelullinen vire. Keskustelun aikaan pohdinta eläinten oikeuksista Britanniassa oli yltynyt jo valtavirraksi. Eläinten julman kohtelun kieltävä laki oli säädetty 11 vuotta aiemmin, ja laki oli antanut kehykset myös eläinkokeille. Keskustelu vivisektiosta kävi erittäin kiivaana. Eläinten suojelijat näkivät eläinkokeet ihmisen julmuuden huipentumana ja moraalisena rappiona.

Koska teema oli niin ajankohtainen, on luonnollista, että Light-lehden keskustelu siirtyi vivisektioon varhaisessa keskustelun vaiheessa. Näin kävi, vaikka alkuperäinen

Oxford Dictionary of National Biographyyn (tarkastettu 18.2.2021).

13 Pennyn käyttämä sana profanation on tässä käännetty häväistykseksi. Kursiivi alkuperäinen.

14 Ives (1831-1879) oli ollut Yale Medical Schoolin ja myöhemmin New Yorkin kaupunginyliopiston professori.

15 T. W. nostaa esimerkeiksi Ivesin teoksesta Raamatun jakeet 1 Moos 20, 30, ja 2:7 (Light 30.4.1887, 196). 
kysymys oli ollut periaatteellinen ja koski mahdollisuutta eläinten sielujen kuolemattomuudesta eikä niinkään eläinten kyvystä ajatella tai tuntea tässä elämässä. ${ }^{16}$ Eläinten oikeuksien historiaa ja antivivisektionismia ${ }^{17}$ on tutkittu runsaasti, ja tutkimuksessa on aiemminkin havaittu yhteys 1800 -luvun jälkipuolen esoteerisiin virtauksiin. A. W. H. Bates huomioi hengellisen käänteen merkityksen ja mainitsee, miten ajattelun kenttään sekoittui klassista pakanuutta, hinduismia ja okkultismia (Bates 2017, 45, 57). ${ }^{18}$ Spiritualistien kokemusperäistä tietoa eläinten hengistä ei ole kuitenkaan tarkasteltu tässä yhteydessä, ${ }^{19}$ joten keskustelu täydentää myös käsitystämme eläinsuojelukysymyksestä 1800-luvun Britanniassa, josta ajattelu levisi muualle maailmaan.

Aiemmin oli esillä E. M.:n huomio siitä, miten okkultistit usein tuomitsivat eläimet alhaisiksi, mistä syystä niitä saattoi kohdella miten huvitti. Onkin niin, että kysymys eläinten sielusta toi esiin kysymyksen ihmisen ja eläimen suhteesta toisiinsa. Niinpä E. M. toteaa, että inmisten on oltava eläimille oikeudenmukaisia ja armollisia, koska niillä on kuolematon sielu ja etenkin koska ihmisellä itsellään on sielu, jonka ytimessä ovat oikeudenmukaisuuden ja armollisuuden periaatteet. Jos eläimet kärsivät huonosta kohtelustamme, hän sanoo, me kärsimme itse vielä enemmän. E. M. tarkoittaa, että ihminen tuottaa sielulleen korvaamattoman tuhon toimimalla ihmisyyden vastaisesti. Hän lopettaa kirjeensä: "Tuottakoon keskustelunavaus sivuillanne kaikille spiritualisteille heidän uskonsa tuottaman velvollisuuden eläimiä kohtaan!". (Light 12.3.1887, 117.) Ei siis ollut itsestään selvää, miten ihminen sai luomakunnan kruununa toimia. A. J. Penny puolestaan kirjoitti, että jos koiran psykologiaa ymmärrettäisiin paremmin, "koirien vivisektori ajattelisi kauhulla murhiensa petollisuutta ja alentavan työnsä hedelmätöntä

16 Kysymyksestä eläinten kyvystä tunteisiin darwinismissa erinomaisesti artikkeleissa teoksessa Richardson (2013, passim), ennen Darwinia erityisesti Spencerin artikkeli mainitussa teoksessa.

17 Tässä artikkelissa käytetään termiä antivivisektionismi, kun tarkoitetaan vivisektion vastustamiseen liittyvää liikehdintää erotuksena antivivisektiosta, joka tarkoittaa yleisesti vivisektion vastustamista.

18 Myös esimerkiksi 1800-luvun jälkipuolen brittiläisten kveekareiden suhdetta vivisektioon on tarkasteltu (Glaholt 2012); teosofian ja antivivisektion yhteyksistä Viswanathan (2011) ja viitteistä saksalaisen antivivisektionismin teosofisista yhteyksistä, Treitel (2004, 61-63, 86). Vivisektion historiasta tuorein laaja tutkimus on Boddice (2021).

19 Esimerkiksi Li (2012) lähes ohittaa ei-normatiivisen uskonnollisuuden ja näkee tarkastelemansa sekularismin vastakohtana kristillisen vakaumuksen. Bates (2017) ohittaa spiritualismin ja teosofian käytännön vaikutukset keskusteluun lyhyillä maininnoilla (esim. 86-87). Lachapelle \& Healey (2010) nostavat seanssien merkityksen esiin lyhyesti. Lähelle tulee Howell, joka tarkastelee koiralemmikkien hautaamiseen liittyvää epäortodoksista ajattelua, rakkaan koiravainajan jälleennäkemisen toivetta (Howell 2015, 136-49), mutta hänkin käsittelee valtavirtaiseen kristilliseen vakaumukseen liittyvää epäortodoksisuutta. Klassikkona pidettävä French (1975) ohittaa esoteeriset virtaukset tarkastelussaan antivivisektion historiasta Britanniassa. 
julmuutta" (Light 19.3.1887, 129).

Keskustelussa nousee esiin englanninkielisen termin/käsitteen humanity kaksimerkityksisyys sekä ihmiskuntana että inhimillisyytenä. Tätä käytti hyödykseen nimimerkki S. W. Edgbastonista kirjoittaessaan viitaten E. M.:n kirjoitukseen armosta ja inhimillisyydestä (humanity). Ihmiskunnan tulee kohdella eläimiä inhimillisesti tässä elämässä. Hänelle humanity oli eläinten yhteydessä "pyrkimystä kohdella alempia eläimiä lempeydellä ja olla tuottamatta niille tarpeetonta kipua". Hän katsoo, että ihmisten velvollisuus eläimiä kohtaan on ennen kaikkea auttaa niitä kaikin mahdollisin keinoin nyt. (Light 26.3.1887, 140.)

Ajatukseen yhtyivät muutkin. Keskustelussa saatiin jännittävä käänne, kun huhtikuun 9. päivän numerossa julkaistiin Roomassa 28.3. päivätty kirje. Sen oli laatinut itse Anna Kingsford (1846-1888). ${ }^{20}$ Anna Kingsford oli kouluttautunut läkäriksi Pariisissa aikana, jolloin se oli vielä mahdotonta naisille Britanniassa (ja vieläpä tarkoituksellisesti sairaalassa, joka johti eläinten käyttöä eläinnkokeissa ja jota paheksuttiin Britanniassa voimakkaasti) voidakseen asiantuntijana parantaa eläinten oloja tieteen sisältä päin. ${ }^{21}$ Kingsford oli kasvissyöjä ja laatinut myös loppututkielmansa teemasta. Hänet tunnettiin myös naisasianaisena ja mystikkona. Vakaumukseltaan hän oli teosofi. Hän sairasteli jo kirjettään kirjoittaessaan ja menehtyi vajaan vuoden päästä keuhkotautiin. Hän aloittaa kirjeensä vetoamalla sairauteensa: hän on ollut liian kauan sairaana ja kirjoittaa olevansa yhä liian invalidi käydäkseen minkäänlaiseen kiistaan. Siitä huolimatta hän haluaa tuoda näkökulmansa esiin. Hän haluaa kertoa - omien sanojensa mukaan - pateettisen tarinan, jonka hän oli kuullut tunnetulta spiritualistilta Pariisissa. Eräässä pariisilaisessa seanssissa "selvänäkijä22 näki ja kuvaili läsnä olevia henkiä", hän kirjoittaa. "Osallistujien joukossa oli muukalainen, englantilainen herrasmies, jota kukaan huoneessa olija ei tuntenut. Miestä kohden katsoen selvänäkijä yhtäkkiä huudahti: 'Kuinka outoa! Tuon herrasmiehen takana näen suuren setterin, joka pitää tassua kiintymyksellä hänen olkapäällään ja katsoo häntä kasvoihin aidolla kiintymyksellä." Kingsford jatkaa, että herrasmies oli liikuttunut ja pyysi lisäkuvausta koirasta. Sen saatuaan hän kyynelet silmissään totesi setterin olevan hänen poikavuosiensa uskollinen kumppani. Hän oli menettänyt vanhempansa nuorena, joten koira oli ollut hänen alituinen seuralaisensa. Kun koira oli kuollut vanhuuttaan, hän oli itkenyt katkerasti. Selvänäkijä sanoi: "Tämä koi-

20 Kingsfordin teosofisesta sitoutuneesta ajattelusta eläimiin liittyen ks. myös Viswanathan (2011, 445-447); vertaa French, joka ei huomioi lainkaan Kingsfordin esoteerisia sitoumuksia (1975, 390-391).

21 Pariisilla oli johtava asema eläinkokeissa ylipäätään (Kirk 2016, 123-4).

22 Kingsford käyttää termiä clairvoyante, ei meedio. 
ranne henki on nyt vartijanne. Se ei koskaan jätä teitä, vaan rakastaa teitä täydellisellä omistautumisella." "Eikö tämä olekin kaunis tarina?", Kingsford kysyy. (Light 9.4.1887, 161.)

Kingsford ei tähtää vastaamaan kirjeellään vain J. C. :n alkuperäiseen kysymykseen ja näin esimerkillään vakuuttamaan, että eläimillä tosiaan on ikuiset sielut. Hänen kirjeensä pääasiallinen viesti vasta seuraa tätä muisteloa Pariisista ja liittyy eläinten kohteluun tässä elämässä. Tuntuu, että J. C.:n kysymys on yhdistynyt vahvasti hänen mielessään keskusteluihin, joita hän oli vastikään käynyt Nizzassa. Hän oli ollut siellä pariisilaisia teosofipiirejä johtaneen Lady Caithnessin kanssa. Tälle oli lähetetty uusi okkultistisen seuran lehti, jossa oli ollut molempia naisia syvästä surettanut luku. Teksti oli hyökännyt vahvasti eläinten sielujen kuolemattomuutta vastaan. Kingsfordin mielestä on "shokeeraavaa", että kukaan, joka väittää omaavansa pienintäkään okkultismin ymmärrystä, voi väittää ettei eläimillä olisi kuolematonta sielua. Hän sanoo, että kristinuskon tulisi korjata ajatuksiaan solidaarisuudesta kaikkea elollista kohtaan ja että tässä kysymyksessä Buddha ylittää Jeesuksen. Tästä hän puolestaan pääsee senhetkiseen olinpaikkaansa Roomaan ja toteaa, kuinka paavin kaupungissa "nämä kristityt" harjoittavat mustasydämistä julmuutta eläimiä kohtaan. Kun hän saapui kaupunkiin, hän oli joutunut huonosta kunnostaan huolimatta nousemaan vaunuistaan toruakseen "ilkeää lasta, joka kidutti pylvääseen sidottua pientä koiraparkaa potkimalla ja tallomalla sitä". (Light 9.4.1887, 161.) Kingsford paheksuu roomalaisten asiaan puuttumattomuutta. ${ }^{23}$ Huonot kokemukset Roomassa eivät päättyneet tähän. "Tänään näin ison, paksusaap-

23 Guazzaloca on tarkastellut eläinsuojelukysymystä 1800-luvun jälkipuolen Italiassa ja osoittanut, että eläinten suojelu on siellä käynnistynyt varsin myöhään. Pioneereja tässä eivät olleet italialaiset itse, vaan brittinaiset, jopa niin, että eläinten suojelua pidettiin ulkomaisena, protestanttivanhapiikojen touhuna ja etenkin nimenomaan englantilaisen vanhojenpiikojen puuhasteluna. Brittinaisten rooli olikin merkittävä. Triestessä konsulinna Isabel Burtonista tuli paikallisen eläinsuojeluyhdistyksen puheenjohtaja vuonna 1852 ja antivivisektionisti. Italialaisen eläinsuojeluaatteen keskukseksi muodostuneessa Torinossa puolestaan Anna Winter, Sutherlandin kreivitär, vaikutti vahvasti Torinon eläinsuojeluyhdistyksen perustamisen taustalla 1871. Torinon yhdistyksestä tuli vaikutusvaltainen - vuonna 1879 kuningatar Victoria suostui yhdistyksen kunniajäseneksi. Italiassa suojelun fokuksessa olivat erityisesti vetoeläimet ja niiden kuljettajat - mikä näyttäytyy varsin utilitaristisena - eikä esimerkiksi eläinkokeiden vastustus noussut Italiassa mitenkään erityisesti esiin. Hyötynäkökulma korostui: 1899 pidettiin jopa konferenssi otsikolla "Eläinten suojelu ja miksi ulkomaalaiset eivät vieraile Napolissa". (Guazzaloca 2017, 262-63, 266; eläinsuojelun sukupuolittumisesta ks. myös Viswanathan 2011; Kraft 2016, 573.) Samankaltaiseen sukupuolitettuun havaintokenttään liittyi myös se, miten tärkeässä roolissa naiset olivat esoteerisella kentällä. Sitä kautta he vaikuttivat myös monilla filantropian alueilla ja naisasialiikkeessä. (Kaartinen \& Leskelä-Kärki 2020; Coudert 2019; Kaartinen 2017; Kemppainen 2017; Dixon 2001; Braude (1989) 2001; Owen (1989) 2004.) 
paisen moukan potkaisevan muuliaan suuhun silkasta mielivaltaisuudesta. Väitä vastaan näille julmureille tai heidän papeilleen, ja he vastaavat: 'Kristityillä ei ole mitään velvollisuuksia kuolevaisia eläimiä kohtaan'. Näin paavi on heille kertonut". (Light 9.4.1887, 161-62.) Kingsford pitää kirkon toimettomuutta puolustaa eläimiä kammottavana ja tuomittavana eikä voi käsittää, miten tällaisen toiminnan peruste voi olla se, että eläimet ovat sieluttomia. "Maapallosta on tullut helvetti tämän opin vuoksi", hän kirjoittaa, ja huudahtaa, että "jos jollakin elävällä olennolla maan päällä on oikeus Taivaaseen, varmastikin eläimillä on siihen suurin oikeus, niin suuria niiden kokemat kärsimykset ja vääryydet ovat". Lopuksi Kingsford vetoaa: "Mystikkona ja okkultistina minä tiedän, etteivät eläimet tuhoudu kuolemassa, mutta jos voisin epäillä sitä - - minun tulisi myös epäillä Jumalan oikeudenmukaisuutta. Kuinka voisin sanoa, että Hän on oikeudenmukainen ihmiselle, jos Hän on niin hirvittävän epäoikeudenmukainen rakkaille eläimille?". (Light 9.4.1887, 162.) On selvää, että Kingford oli hyvin tietoinen paavi Pius IX:n (k. 1878) linjauksesta, jossa paavi ei ollut ollut valmis tukemaan eläinsuojelua, jottei syntyisi ajatuksia, että eläimillä olisi oikeuksia (Bates 2017, 47).

Tavalla tai toisella Anna Kingsfordin kirjoitus tavoitti saman tien tuon uuden okkultistisen lehden toimittajan F. W. Readin, joka kirjoitti huhtikuun 19. päivätyssä kirjeessään, että Kingsford selvästi viittasi hänen lehteensä Spiritual Reformer. Read oli vieläpä itse kirjoittanut Kingsfordin viittaaman jutun. Read esittää, että hän ei vastusta olentojen säilymistä (survival) vaan ajatus kuolemattomuudesta (immortality) on mahdoton. "En pysty uskomaan joka päivä kuolevien miljoonien kärpästen kuolemattomuuteen", hän kirjoittaa, ja jatkaa, ettei usko Kingsfordin tosissaan puolustavan muuta kuin jonkin aikaa kestävää sielun säilymistä. Tällaista hänen kirjoituksensa ei vastustanut. (Light 7.5.1887, 208.) Seuraava keskusteluketjuun liittyvä kirje on yllätyksettömästi Kingsfordin vastaus Readille. Kirje on päivätty Roomassa 8.5. ja se julkaistiin 14.5. Siinä hän myönsi, että Readin lehdestä täytyi olla kyse, mutta tarkensi, ettei ollut koskaan itse pitänyt lehteä edes kädessään vaan Lady Caithness oli lukenut hänelle siitä valikoituja otteita. ${ }^{24}$ Kingsford korosti katsovansa brahmanistisen, buddhalaisen, platonistisen ja hermeettisen ajattelun oppilaana, että yksikään eläin ei katoa, ei edes alhaisin. Kingsford sanoo kärpästen kuuluvan kabbalistiseen Beclzebubin [sic] kuningaskuntaan. ${ }^{25}$ Kai-

24 Read pian harmitteli, että Kingsford viittasi kirjeessään tekstiin, jota ei ollut itse lukenut. Jos Kingsford olisi lukenut eteenpäin, hän olisi havainnut, että Readin teksti oli likimain identtinen Kingsfordin omiin oppeihin tässä jälkimmäisessä kirjeessä. Read ei käsitä, miten Kingsfordin väärinymmärrys oli voinut syntyä. (Light $21.5 .1887,231$.

25 Tähän kuningaskuntaan liittyen kohdisti kysymyksen Kingsfordille puolestaan Eliza Boucher, joka oli kiinnostunut kuulemaan, missä okkulttisissa teoksissa tämän "Beelzebubin kuningaskunta" mainitaan. Hän haluaisi lukea asiasta lisää. (Light 21.5.1887, 231.) 
killa eläimillä oli roolinsa, ne kaikki pyrkivät ylöspäin, korkeammalle tasolle, ihmiseksi, hän kirjoittaa. "Kaikki evoluutio kiirehtii kehittyäkseen ihmiseksi", hän päättää. (Light 14.15.1887, 219. ${ }^{26}$ Readin vastauksen jälkeen keskustelu käytännössä jatkui enää kesäkuussa tästä keskustelusta juonnetuilla kirjeillä, joilla ei ollut enää mitään tekemistä alkuperäisen kysymyksen kanssa.

Koska keskustelussa Kingsford, antivivisektionismi ja teosofia saivat suhteellisesti paljon palstatilaa, on kiintoisaa, että teosofeista tuossa vaiheessa kiistatta kuuluisin, Helena Blavatsky loisti poissaolollaan keskustelussa. Vain yhden kerran hänet nostetaan esiin eikä silloin mairittelevassa valossa. Nimimerkki Cantab. viittaa "Blavatskyn innoittamana" ilmestyvä Le Lotus -lehden huhtikuun numeroon, jossa kirjoittajan mielestä barbaarisen eläinkokeen tuloksia pidettiin "hyvin kiinnostavina". Cantab. on tietoinen Blavatskyn näkemyksistä, sillä hän vaatii nyt julkistettavaksi onko se, että Le Lotus ilmestyisi Blavatskyn inspiroimana, väärä väite ja toiseksi, jos se ei sitä ole, onko Madame Blavatsky muuttanut mieltään suhteessa vivisektioon ja onko teosofian näin nähtävä sallivan julmat käytännöt, kun etsitään omaa etua välittämättä sen hinnasta muille. Tämän kirjoittaja näkee vivisektion tyypillisenä materialismin lopputulemana. (Light 4.6.1887, 256.) Koska Lightin keskustelussa selvästi käy ilmi, että spiritualistit lukivat teosofien julkaisuja ja toisinpäin, voi hyvällä perusteella ihmetellä muiden viittausten puuttumista Blavatskyn erityisen näyttävään The Theosophistin kolmessa numerossa (tammi-, helmi- ja maaliskuu) jatkuneeseen, vain vuosi takaperin ilmestyneeseen artikkeliin. Edes Kingsford, itsekin teosofi, ei viittaa Blavatskyn artikkeliin.

Tuossa vuoden takaisessa artikkelissaan Blavatsky oli käyttänyt vahvaa kieltä ja hyökännyt "eurooppalaisia" vastaan esittämällä, että he eivät lainkaan välitä eläinkunnan kuolintuskista vaan "uhraavat päivittäin miljoonia viattomia, harmittomia elämiä", mutta, hän jatkaa kitkerästi: "niin sen on oltavakin Kruppin tykkien ja tieteellisen vivisektorin aikana" (The Theosophist, Jan 1886, 243). Kingsfordin tavoin Blavatsky näkee parempana itämaisen uskonnon, joka kunnioittaa "jokaisen tuntevan eläimen elämää elefantista hyttyseen". Blavatsky tuomitsee kristinuskon näkemykset suhteessa eläimiin ja muistuttaa, miten papisto oli orjuudenvastustajienkin ankarin vihollinen - Raamattu kädessä. (The Theosophist, Jan 1886, 248.) Hän korostaa myös sitä, miten kirkon käsityksiä eläinten sieluttomuudesta on jatkuvasti haastanut arki, etenkin katolisten

26 Samaisessa lehdessä myös E. M. kiirehti syyttämään Readia: tuhoamalla evoluution tikapuiden alemman tason hän tekee itse ihmisen mahdottomaksi, sillä ei voi olla ylätasoa ilman ylätasoa. Hän huomioi, että olisi kiintoisaa kuulla, mistä Read on saanut oppinsa. (Light 14.5.1887, 219.) Read vastasi (seuraavassa numerossa) E. M.:lle lyhyesti vain toteamalla, että Spiritual Reformer opettaa, että "ihminen tulee ihmiseksi kehittymällä alemmista muodoista" (Light 21.5.1887, 231). 
pyhimysten toimet eläinten henkiin herättämisessä (The Theosophist, Jan 1886, 249 ja Feb 1886, 296-97). ${ }^{27}$ Hän ei ymmärrä tappamista urheiluna ja pitää vivisektionistien, "teurastaja-akateemikkojen", työtä kammottavana. Se on hänen näkemyksensä mukaan kidutusta, johon verrattuna metsästys tai teurastus ei ole mitään. (The Theosophist, Jan 1886, 243-245.) Lightin keskustelussa sen sijaan ei suunnattu puhetta eläinten tappamiseen ruuaksi. Todennäköisesti lukijat kuitenkin olivat erinomaisesti perillä keskusteluista, jotka olivat liittyneet etenkin teosofien vegetaristisiin näkemyksiin, joten keskustelu eläinten kaltoin kohtelusta todennäköisesti resonoi lukijoiden mielissä myös teurastukseen liittyviin kysymyksiin. ${ }^{28}$

\section{Eläinten kyvyt}

Light-lehden keskustelu asettui aikaan, jolloin kiihtyvässä määrin oltiin kiinnostuneita paitsi mahdollisuudesta, että eläimillä sittenkin olisi sielu, kysymyksestä eläinten älykkyydestä. ${ }^{29}$ Artikkelissaan Blavatsky oli nostanut esiin tämän kysymyksen erillisenä. Hän lähti liikkeelle aina Descartesista ja hyökkää erityisesti Cuvier'n ja Buffonin kimppuun. Kuka pystyi oikeasti sanomaan, ettei eläimellä olisi älyä, hän kysyy ja kiistää eläinten asettuvan pelkästään vaiston kentälle. (The Theosophist, Feb 1886, 300-301.) Eläinten älykkyydestä oli keskusteltu paljonkin ja soraääniä kuului myös katolisen kirkon piiristä. Esimerkiksi liverpoolilainen pappi J. Worthy oli esittänyt, että mehiläiset ja aasit olivat älykkäitä ja toimivat paitsi vaiston, myös älyn voimalla. (Worthy 1856; ks. myös Bates 2017, 49.)

Ajan ymmärryksen mukaisesti Lightin keskustelussa sielun ja mielen käsitteet eivät olleet erillisiä. Kokemusperäinen koiranomistajien arkitieto kertoi, kuinka esimerkiksi koirilla oli välttämättä oltava mieli ja mielikuvitus. A. J. Penny kirjoittaa, kuinka kukaan, jolla on joskus ollut koira seuranaan, voisi epäillä, etteikö niillä olisi sielua. Hän itse on rakastanut monia koiria ja kaikilla niillä on ollut oma erityinen mielensä. Hän esittää myös, että eläimillä on mielikuvitus, mistä kertoo hänen mukaansa uneksivan koiran haukunta ja hännän heilutus. Rouva Penny viittaa tässä metafyysikko, vivisektionisti G.

27 Blavatsky käy läpi useita eläinten ylösnousemustapauksia jälkimmäisessä osiossa - ja vierittää syytä Tuomas Akvinolaiselle, joka Summassa kieltää eläimen sielun kuolemattomuuden (Feb 1886, 298-99).

28 Varhaisesta vegetarismista ja sen kohtalaisen heikosta linkittymisestä eläinsuojelukysymykseen Suomessa Vornanen (2014, erit. 33-36).

29 Esim. Lachapelle \& Healey (2010, 12-20) tarkastelevat inme-eläinten roolia eläinten älykkyys -keskustelussa. 
J. Romanesiin ${ }^{30}$, joka teoksessaan Mental Evolution in Animals esitti, että kaikilla olennoilla on mieli. (Light 19.3.1887, 128.)

\section{Lopuksi}

Eläinten kyvyistä oli vakuuttunut myös tässä tarkasteltuun keskusteluun tarkkaan ottaen liittymätön, mutta sitä osaltaan jatkava juttu, joka lainattiin Lightiin yhdysvaltalaisesta Chicago Tribunesta. Siinä kysyttiin, miksi raakalaismaisimmat ihmisetkin saattoivat päästä paratiisiin, mutta taitavat, katalampia ihmisiä paremmat olennot suljettaisiin paratiisista ulos. Ja sitä paitsi, artikkeli kysyy, "Mitä olisi Paratiisi, jos vanha Kharon ei koskaan kuljettaisi lautallaan hevosen tai koiran henkeä ylitse Styxin, jos lintu ei koskaan laulaisi elämän puussa tai perhonen räpyttelisi siipiään kukkasissa?". (Light 25.6.1887, 285.) Näin kysyi spiritualisti kesällä 1887 Light-lehdessä useita kuukausia kestäneen keskustelun vähitellen hiljentyessä. Keskustelu kevätkaudella 1887 ei kerro suurista säröistä spiritualistien linjassa suhteessa eläinten sieluihin. Jos sellaisia on ollut, toimitus on jättänyt ne julkaisematta. Pikemminkin spiritualistien linja näyttää yllättävänkin yksimieliseltä - ja myös kokemusperäiseltä. Keskustelu osoittaa ja resonoi myös tähän päivään, miten merkittävä voima kokemusasiantuntijuudella voi olla. Eläinkummituksen nähnyt tai sellaisesta vakuuttavalta taholta kuullut oli valmis haastamaan kokemuksensa avulla ja sen vuoksi jopa kirkollisen oppijärjestelmän. Liian monella oli suoraan tietoa tuonpuoleisesta ja siellä olevista lemmikkieläimistä, jotta sitä saattoi ohittaa.

Ainoa linjasärö syntyi kysymyksestä eläinten sielujen iäisyydestä - ja silloinkin keskusteluun olivat liittyneet teosofit. Tämä nousi esiin lyhyessä Anna Kingsfordin ja F. W. Readin välisessä kiistelyssä. Readin tulkinnan mukaan eläimillä oli sielu, olivathan ne olentoja, jotka olivat osa evoluutiota kohti ihmistä, mutta nämä sielut eivät olleet ikuisia. Kingsford puolestaan piti mahdottomana, että luoduilla olisi erilaiset sielut. Jokainen sielu, vaikka kärpäsen, eli ikuisesti. Molempien näkökulmasta hierarkia oli kuitenkin selvä: ihminen oli luomakunnan kruunu ja siksi erityinen: ihmisen tasolle pyrkivät kaikki luodut. Tämä eri uskonnäkemyksistä muotoutunut hybridinen käsitys, jota eri suunnista tulevat esoteerikot omista lähtökohdistaan muotoilivat, oli riittävä pitämään myös itseään kristittyinä pitäneet spiritualistit tällaisen tulkinnan kannalla.

Tärkeässä roolissa ajattelussa oli erityisesti buddhalaisuudessa merkittävä kaiken ykseys -ajatus, joka suodattui vahvasti esimerkiksi moderniin, 1800-jälkipuolella muotoutuneeseen teosofiaan. Kun kaikki olennot olivat yhteydessä toisiinsa, olivat ne

30 Romanesista vivisektionistina Boddice (2011). 
sitten millä kehityksen tasolla hyvänsä, korkealla tasolla olevan ihmisen tuli asemansa tuoman vastuun vuoksi kantaa huolta alemmalla tasolla olevista, niiden hyvinvoinnista ja vähintäänkin kärsimyksen vähentämisestä. Tämä näkyi keskustelussa Light-lehdessä, ottihan eläinten suojelukysymys nopeasti voiton keskustelusta varsinaisesta alkuperäisestä kysymyksestä eläinten sieluista. Tämäkin kertoo siitä, miten laveasti ristiinkeskusteleva modernin länsimaisen esoterian kenttä oli 1800-luvun jälkimmäisellä puoliskolla. Keskustelu myös paljastaa, miten keskeisessä osassa uskonnonfilosofinen opiskelu oli ylipäänsä ajan esoteerisella kentällä. Toisaalla ei pidä unohtaa myöskään sitä, että myös näennäisen vastakohtaisessa sekularistisessa ajattelussa puolestaan ajatus evoluutiosta vahvisti käsitystä kaikkien elollisten yhteydestä. 1800-luvun viimeisten vuosikymmenien esoteria ei myöskään koskaan irtautunutkaan lähtökohtaisesta ajatuksestaan, että se on tieteellistä ja jopa tiedettä.

Light-lehdessä käyty keskustelu vihjaa kiinnostavasti myös siihen, miten esoterian kenttä sukupuolittui. Kuten keskustelu osoitti, siihen osallistui varmuudella sekä miehï että naisia. Niin spiritualistien kuin teosofienkin piirissä naisilla oli merkittävä rooli. Heillä puolestaan oli vahva rooli monissa muissa yhteiskunnallisissa liikkeissä, kuten tarkasteltuun keskusteluunkin liittyneessä eläinsuojeluaatteessa ja antivivisektionismissa. Esoteria tarjosi viktoriaanisessa Britanniassa naisille kentän, jolla he saattoivat antaa oman äänensä kuulua ja se tarjosi heille myös äänitorven vaikuttaa muilla elämänaloilla. Näin ei olekaan ihme, että monien silmissä esoteria leimautui naisiseksi ja sen mukana esoteeriseksi leimautunut eläintensuojelu samoin. Light-lehden keskustelu näyttää vahvistavan tätä näkemystä vähintään siltä osin, että se ei suinkaan vaientanut naisten ääniä kentältä.

Keskustelu eläinten sieluista ja niiden kuolemattomuudesta spiritualistien parissa ei tietenkään päättynyt keskustelun tyrehdyttyä. Kokemusperäisellä tiedolla oli asiassa selkeästi voimaa. Light-lehdessäkin teemaan palattiin (esim. Light 6.6.1891), ja esimerkiksi brittiläisen spiritualismin keskeisiin hahmoihin kuulunut Emma Hardinge Britten (1823-1899) julkaisi omassa kuukausilehdessään ${ }^{31}$ The Unseen Universe tammikuussa 1893 näyttävästi amerikkalaisen Charles Dawbarnin (s. 1833?) artikkelin otsikolla "Are the Spirits of Animals Immortal". Se korostaa asiaan liittyvien tiedustelujen olleen spiritualistien keskuudessa "loputtomia". Tässäkin artikkelissa yhdistyy vahvasti sielun ja älykkyyden yhteys, kuten Light-lehden keskustelussakin tapahtui: se, että eläimelle voitiin hyväksyä korkeatasoinen ajattelutoiminta, johti väistämättä mahdollisuuteen,

31 Lehden kannessa ilmoitetaan, että se oli paitsi Brittenin täydessä johdossa, omistettu "spiritismille, okkultismille, muinaiselle magialle, modernille mediumismille ja kaikelle, mikä kuvasta ihmisyyden paikkaa, laatua ja suuntaa" (The Unseen Universe, January 1893, kansilehti). 
että sillä oli ihmisen tapaan kuolematon sielu. Dawbarnin artikkeli listaa suuren määrän osoituksia eläinten älystä - tapauksia, jotka jokaisen lemmikinomistajan näkökulmasta olivat itsestään selviä. (The Unseen Universe, January 1893, 489-96.)

Vaikka Light-lehdessä käyty keskustelu painotti erittäin vankasti eläinten kärsimyksien vähentämisen tärkeyttä, vivisektion järkyttävyyttä ja vaikka se päätyi aina korostamaan sitä, miten kaikilla elävillä olennoilla oli lähtökohtaisesti samanlainen, kuolematon sielu, lopputulemana oli kuitenkin ajatus siitä, että ihminen ei ollut eläin vaan eläimistä erillinen luomakunnan jäsen. Ihminen oli kruunu, huipentuma ja tavoitetila, jota kohti kaikkien olentojen sielut pyrkivät. Näin ollen henkihahmoina nähdyt eläinten sielut olivat vain todiste siitä, että alemmillakin olennoilla oli mahdollisuus ikuiseen elämään.

\section{KIITOKSET}

Tekijä kiittää lämpimästi toimittajia ja vertaisarvioitsijoita asiantuntevista ja hyödyllisistä kommenteista ja parannusehdotuksista.

\section{Kirjallisuus}

\section{ALKUPERÄISLÄHTEET}

Light 1887.

The Spiritual Review 1900.

The Theosophist 1886.

Besant, Annie. 1893. Death - and After? Theosophical Manuals Nr 3. Lontoo; New York; Madras: Theosophical Publishing Society.

Dunglas Home, Madame. 1890. The Gift of D. D. Home. Lontoo: Kegan Paul, Trench, Trübner \& Co.

Worthy, J. 1856. "Souls and Instincts of Animals." The Catholic Institute Magazine, (February): 143-49; (March): 175-80.

\section{TUTKIMUSKIRJALLISUUS}

Boddice, Rob. 2011. "Vivisecting Major: A Victorian Gentleman Scientist Defends Animal Experimentation, 1876-1885." Isis 102 (2): 215-37.

Boddice, Rob. 2021. Humane Professions. The Defence of Experimental Medicine, 
1876-1914. Cambridge: Cambridge University Press.

Braude, Ann. [1989] 2001. Radical Spirits. Spiritualism and Women's Rights in Nineteenth-Century America. Toinen painos. Bloomington and Indianapolis: Indiana University Press.

Dixon, Joy. 2001. Divine Feminine. Theosophy and Feminism in England. Baltimore; Lontoo: The Johns Hopkins University Press.

Faivre, Antoine. 2010. Western Esotericism: A Concise History. Kääntänyt Christine Rhone. Albany: State University of New York Press.

Bates, A. W. H. 2017. Anti-Vivisection and the Profession of Medicine in Britain. Lontoo Palgrave.

College History. https://www.collegeofpsychicstudies.co.uk/about/page/id/8/college-history.

Coudert, Allison P. 2019. "There's not much room for women in esotericism, right?" Hermes Explains. Thirty Questions about Western Esotericism, toim. Wouter J. Hanegraaff, Peter J. Forshaw ja Marco Pasi, 71-79. Amsterdam: Amsterdam University Press.

French, Richard D. 1975. Antivivisection and Medical Science in Victorian Society. Princeton: Princeton University Press.

Glaholt, Hayley Rose. 2012. "Vivisection as War: The 'Moral Diseases' of Animal Experimentation and Slavery in British Victorian Quaker Pacifist Ethics." Society \& Animals 20(2): 154-72.

Guazzaloca, Giulia. 2017. "'In the Name of Justice and Compassion' Animal Protection in Italy during the Liberal Age (1861-1914)." Modern Italy: Journal of the Association for the Study of Modern Italy 22(3): 261-74.

Harmainen, Antti. 2020. "Teosofia." Moderni esoteerisuus ja okkultismi Suomessa, toim. Tiina Mahlamäki ja Nina Kokkinen, 91-111. Tampere: Vastapaino.

Hanegraaff, Wouter J., Peter J. Forshaw ja Marco Pasi, toim. 2019. Hermes Explains: Thirty Questions about Western Esotericism. Amsterdam: Amsterdam University Press.

Howell, Philip. 2015. At Home and Astray: The Domestic Dog in Victorian Britain. Charlottesville: University of Virginia Press.

Kaartinen, Marjo. 2017. "Vera Hjeltin teosofinen maailmantyö." Historiallinen Aikakauskirja 115 (2):170-83.

Kaartinen, Marjo ja Maarit Leskelä-Kärki. 2020. "Spiritualismi." Moderni esoteerisuus ja okkultismi Suomessa, toim. Tiina Mahlamäki ja Nina Kokkinen, 53-70. Tampere: Vastapaino. 
Kemppainen, Mikko. 2017. "'Korkein olkoon kanssamme!' Kirjailija Hilda Tihlä ja teosofia suomalaisessa työväenlehdistössä vuosina 1910-1918." Historiallinen Aikakauskirja 115(2): 184-97.

Kirk, Robert G.W. 2018. "The Experimental Animal. In search of a moral ecology of science?" The Routledge Companion to Animal-Human History, toim. Hilda Kean ja Philip Howell. Lontoo: Routledge, 121-46

Kokkinen, Nina ja Tiina Mahlamäki. 2020. "Näkökulmia esoteerisuuteen ja okkultismiin." Moderni esoteerisuus ja okkultismi Suomessa, toim. Tiina Mahlamäki ja Nina Kokkinen, 11-29. Tampere: Vastapaino.

Kraft, Siv Ellen. 2016. "Theosophy in Norway." Western Esotericism in Scandinavia, toim. Henrik Bogdan ja Olav Hammer, 570-77. Leiden: Brill.

Li, Chien-hui. 2012. "An Unnatural Alliance? Political Radicalism and the Animal Defence Movement in Late Victorian and Edwardian Britain." EurAmerica 42, No. $1: 1-43$.

Owen, Alex. (1989) 2004. The Darkened Room. Women, Power, and Spiritualism in Late Victorian England. Chicago; Lontoo: The University of Chicago Press.

Owen, Alex. 2004. The Place of Enchantment. British Occultism and the Culture of the Modern. Chicago; Lontoo: The University of Chicago Press.

Richardson, Angelique, toim. 2013. After Darwin: Animals, Emotions, and the Mind. Amsterdam; New York: Rodopi.

Roussillon-Constanty, Laurence ja Sara Thornton. 2018. "Comforting Creatures: Changing Visions of Animal Otherness in the Victorian Period." Cahiers Victoriens \& Édouardiens (Online) 88:1-11.

Treitel, Corinna. 2004. Science for the Soul. Occultism and the Genesis of the German Modern. Baltimore; Lontoo: The Johns Hopkins University Press.

Vornanen, Jukka. 2014. Kaswisruokaiset wegetariaanit. Kasvissyönnin varhaisvaiheet Suomessa vuosina 1865-1910. Pro gradu -tutkielma, kulttuurihistoria. Turku: Turun yliopisto. 